\title{
BIOCHEMICAL STUDIES OF THE MURINE LEPROSY BACILLUS (Part 2)
}

ON THE RESPIRATORY METABOLISM OF THE MURINE

\section{LEPROSY BACILLUS}

\section{Tonetaro ITO}

(Leprosy Section, Research Institute for Microbial Diseases, Osaka University)

\section{Ryuzo SONODA}

(Department of Dermatology, Osaka University Medical School)

This paper deals with the influences of many substrates known as nutritious elements or accelerating substances and of organ and murine leproma extracts of rats upon the respiration of the murine leprosy bacillus which had been treated with trypsin and centrifuged.

The results obtained are below:

1) Seventeen substrates, such as glycelin, succinate and vitamin $B_{i 2}$, did not accelerate the respiration of the bacillus in single addition. When liver or testis extract inactivated $60^{\circ} \mathrm{C} 30 \mathrm{~min}$. was combined with succinate, the respiration is accelerated.

2) Untreated murine serum prevented the respiration. Liver extract, when inactivated, produced no influence. Testis extract showed acceleration of which intensity was stronger whed untreated than when inactivated. Acceleration was observed when extracts of murine leproma in liver, testis or subcutaneous tissue were applied. In these extracts inactivation produced more intense acceleration than untreated.

Attention should be paid to the fact that extracts of various organs and murine leproma accelerate the respiration of the murine leprosy bacillus.

\section{鼠瀬菌の生物化学的研究}

\section{第 2 報鼠癩菌の呼吸に関する研究 \\ 大阪大学微生物病研究所瀨即究部（主任：西村真二博士） \\ 伊藤 利根太 郎 \\ 大阪大学医学部皮有科教室（主任：蒜浪得二教授)}

園田龍兰

(昭和 32 年 6 月 10 日受稿)

緒
私どもは先の第一報におうて, 感染組織ふら鼠䝿菌を

純粋にしかも生のまま出来るだけ収量多くとり出せる力 法につき研究した結果,トリプシン前処置遠沈集菌法が 最もすぐれていることを報告した。今回はこの方法によ 
つて集めた菌を使用して，鼠霨菌が如何なる物質代謝を 営をかをしらべる手はじめに，先ず菌の乎吸について。 如何なるメヂウムがこ礼定阻止し或証盛ならし成るか について実験を行うことにした。用いた基質は諸種の紬 菌培地として既に知ら礼た栄養素，及び発育促進物質を 単独或は複合の形で用い，又鼠瓎菌に対して泣木モであ るラットの各歲器から抽出した成分に就ても行つた。以 下にその成樍を述べたい。

\section{実験材料及び方法}

供試菌：実跧に際しては毎回，熊本珠鼠濑菌のラット

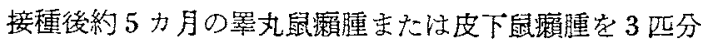
とり出し、トリプシン前处置遠沈集菌法によつて得た菌
体を蒸溜水菌浮游液として用いた。

基質：各基質の作成法，濃度は表】の通りである。

綏衝液： $1 / 5$ M橉酸悢衝液 $\mathrm{pH} 7.2$ を用いた。

計測実施法：鼠蝜菌の呼吸法ワールブルグ检生計を用 いて直接法で計測した。ワールブルグ検圧計容器の各 1 個に壮，菌体 $600 \mathrm{mg}$ (湿潤菌) を蒸溜水 $1.2 \mathrm{cc}$ で浮游 せし的た菌夜及び潾酸綏㣫液 $0.5 \mathrm{cc}$ 主主に，20\% K

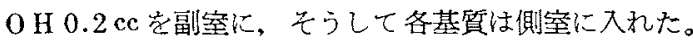
各実験に際しては同一材料，同一条件の実験詨照を用意 した。実硢操作は可及的無菌的に行つたが雑菌による影 響を避けるために盛夏の候を避け，気温 $9^{\circ} \mathrm{C} \sim 19^{\circ} \mathrm{C}$, 気死 $758 \mathrm{mmHg} \sim 770 \mathrm{mmHg}$ ，水温 $37^{\circ} \mathrm{C}$ の条件下に検 圧計振璗 2 時間值を観察した。

第I表 基質の作成法及び使用濃度

\begin{tabular}{|c|c|c|}
\hline 基質 & 成 & 菌液に対する㵖度 \\
\hline 告理的食壏水 & 苩局法減菌食垭水 & $10 \%$ \\
\hline グリセリン & 1/10Mクリセリン & $5 \%$ \\
\hline 可溶性潑粉 & 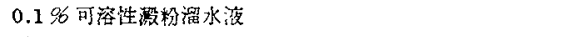 & $5 \%$ \\
\hline クルコーゼ & 1/10 M クルコーゼ & $5 \%$ \\
\hline ポリタミン & 3.3 唋术り夕ミン & $5 \%$ \\
\hline コハク酸 & 1/10M コハク酸 & $5 \%$ \\
\hline クエン酷ソータ & 1/10 M クエン酸ソータ & $5 \%$ \\
\hline aータトグルタル酸 & $1 / 10 \mathrm{M} \alpha-タ ト ク ル タ ル$ 酸 & $5 \%$ \\
\hline アスパラギン & 1/10 M アスパラキ⿺ン & $5 \%$ \\
\hline アスパラギン酸 & 1/10Mアスパフギン段 & $10 \%$ \\
\hline クルタミン & 1/10 M ルルタミン & $5 \%$ \\
\hline クルタミン酸ソータ & 1/10 M ダルタミン酸ソータ & $5 \%$ \\
\hline Tween 80 & $0.5 \% 0$ Tween 80 & $5 \%$ \\
\hline A T P & $500 \mathrm{mg} \not 6$ A T P & $10 \%$ \\
\hline 硫酸マソネシウム & $1 / 100 \mathrm{M} \mathrm{Mg} \mathrm{SO}$ & $5 \%$ \\
\hline $\mathrm{VB}_{12}$ & $0.5 \gamma \quad V_{12}$ & $5: 36$ \\
\hline 葉 酸 & $1 \mathrm{mg}$ 葉酸 & 5.6 \\
\hline ラット肝铀出液 & 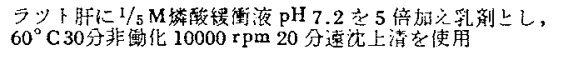 & $5 \%$ \\
\hline 醇母深游液 & 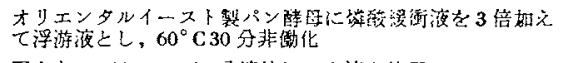 & $10 \%$ \\
\hline 硣母抽旦液 & 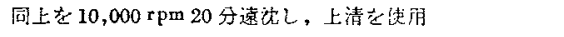 & $10 \%$ \\
\hline
\end{tabular}

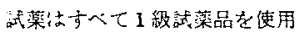

\section{実 験 成 績}

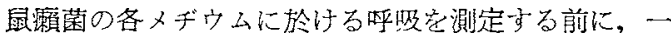

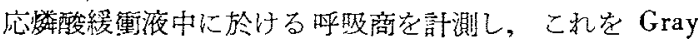
(1)の行つた成績と比輘したところ，我等の成績は R $Q$ 0.62 尔し，Gray(2)の0.7 と近似した值で他の Mycobacteria の場合とも類仙した。次に各単独基筫について 述べる。

\section{I＼cjkstart単独基質による影響}

成績は表 2 の如く，大部分の基質は鼠霟菌の呼吸に対 して無影響でかつだ。が，栄養素と考えられる物㗨中
1/10Mアスパラギンを菌液汇対し $5 \%$ の濃度に用いたる

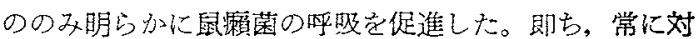
照に較べて 2 時間以内に約 $30 \%$ の呼吸增拁を示した。

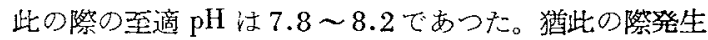
せるアンモニアをConwey 定量法で検出することが出 来た、然るに一方了スパラギン酸は呼吸に無影響であつ た。此の実験の詳細恔徯報に讓る。

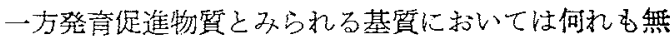
影響であつた。次に醉母浮游液は呼吸を促進したが，て の抽出液法呼吸を促進しなかつた。 
第 2 表 単独基犋の鼠瀬菌の呼吸に及ぼす影響

\begin{tabular}{|c|c|c|c|c|}
\hline 基 啠 & 対 照 & 基質添加 & 判 & 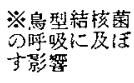 \\
\hline 生理的食壏水 & $38.7 \mu 1$ & $38.5 \mu l$ & 無影眇 & - \\
\hline ケリセリン & 45.2 & 45.2 & " & 促 進 \\
\hline 可溶性镫粉 & 44.9 & 43.7 & " & - \\
\hline ケルコーゼ & 40.5 & 40.4 & " & 促 進 \\
\hline ポりタミン & 39.7 & 40.3 & $"$ & - \\
\hline コハク酸 & 50.1 & 50.0 & $"$ & 促 進 \\
\hline クェン酸ソータ & 39.8 & 39.3 & $"$ & 無影短 \\
\hline аーケトクルタル酸 & 60.3 & 60.1 & " & 促 慥 \\
\hline アスバラギン & 57.3 & 75.5 & 促 進 & - \\
\hline アスパラギン酸 & 54.1 & 53.2 & 無影篦 & 無影管 \\
\hline クルタミン & 52.7 & 50.9 & $"$ & $\cdots$ \\
\hline タルタミン酸ソータ & 48.5 & 48.6 & " & 促 浩 \\
\hline Tween 80 & 46.8 & 46.0 & " & - \\
\hline $\mathrm{VB}_{12}$ & 53.2 & 52.4 & $"$ & - \\
\hline 萎 酸 & 43.4 & 43.1 & $"$ & - \\
\hline 醂母抽出液 & 49.6 & 49.9 & " & - \\
\hline 醉母浮游液 & 45.3 & 66.1 & 促 澌 & - \\
\hline
\end{tabular}

※山村結核菌の生化学（1955）による。

\section{II 複合基質による影嫘}

複合基質の呼吸に及法等は表 3 の通りである。即 ち，一般 Mycobacteria の炭素源として知られたダリセ リンは，単独基質の形では剖項の如く乎吸に対し無影製 であつたので, $500 \mathrm{mg} \%$゙ブノン三酸 (A T P), $0.5 \%$ Tween $80 ， 5 \%$ \%ット肝抽出液（非動化），10\% 醉母抽出液 及び $10 \%$ 醉母浮游液（共に非働化）学加之 て複合基質として用いたがこの場合も促進しなかつた。 他の炭素源としての可溶性潜㸮及びグルコーゼにラット 肝抽出液を加え複合の形とした場合す亦舫影響であっ
た。然るに TCA-cycle (トリカルボン酸サイクル)に関 与する有機酸中のコハク酸は単独では乎吸定促進しない が，ラット肝抽出液（非働化），ラット睪丸抽出液（非

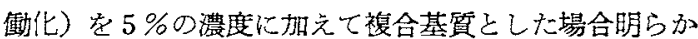
に鼠瀨菌の呼吸を促進した。即台，対照に比へて 2 時間 以内に約 $25 \%$ の呼吸増加があつた。此の場合モルモッ トの肝抽出液を加えた基質も办挐吸を促進した。

その他グルタミンにラット肺抽出夜を加えたものでは 無影響であつた。

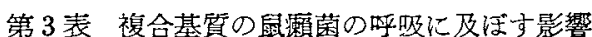

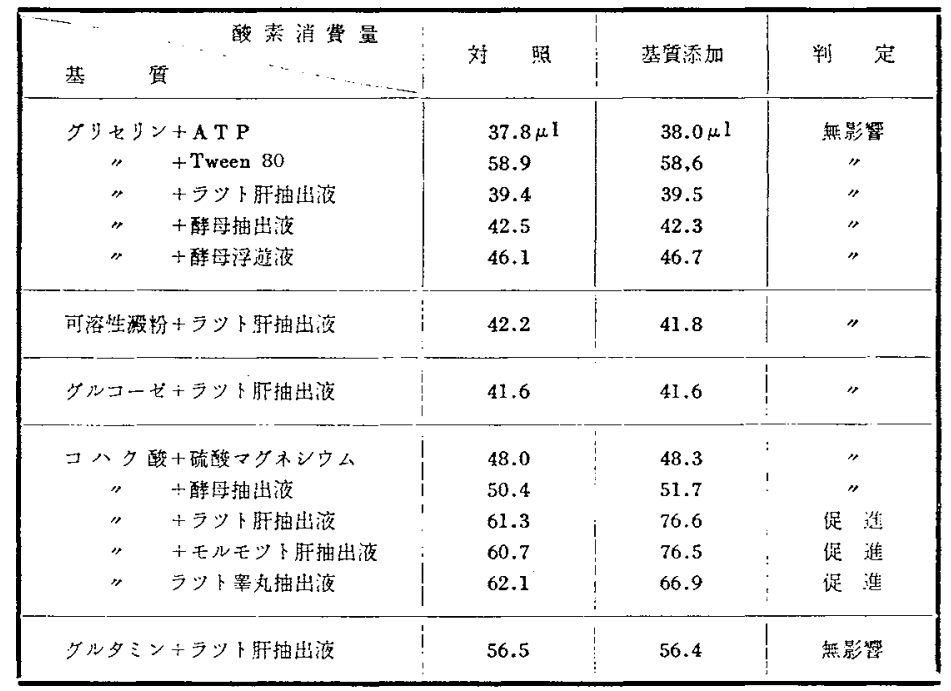




\section{III ラットの血清及び蔵器抽出液による影響}

動物血清が諸㮑抗酸菌の発育に好影響を与兄ること流

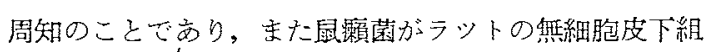
織液中において，スライド上に発育したという中村(2)，

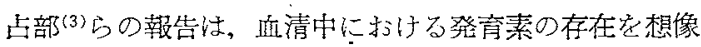
するに充分である。更に鼠瀨菌がラットの肝及び罢丸内 において旺盛な発育振りを示すること，及び最近われら (4)の行つたラット朋抽出液による鼠睥菌スライドカルチ ユフの成續は，二礼等脿器中にある菌発育菜の存在を否 定し得ないし，文前項のコハク酸においてラット肝抽出 液の示した役割は，そこに何等少促進物質の潜在定示咳 するすのと考元ら机る。そこで先ずこれらの血清及び践 器拍出液単独の鼠霜菌呼吸作用に及注す影響をしらべ た。その成績は以下のようであつた。

健康ラット血清：血清を生のまま $15 \%$ の基質として 用いた場合は明らかに鼠霜菌の㭔吸を阻害した。即を， 呼吸汶対照に比べて 2 時聞以内に $86 \%$ 以下となつた。 然るにこ礼を $60^{\circ} \mathrm{C} 30$ 分非㗢化した場合は $20 \%$ 定使用 しても無影響であつた。

健康肝抽出液: 抽出液の作り方は煡康ラット肝 $2.5 \mathrm{~g}$ $K^{1 / 5}$ M燐酸緩衝液 $\mathrm{pH} 7.2$ を $2.5 \mathrm{cc}$, 蒸溜水定 $2.5 \mathrm{cc}$ 加 えてホモヂナイザーで 3 分間乳触とし，承室内に 1 時間

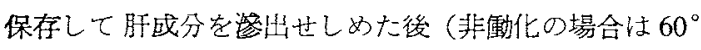
C 30 分加熱)，10,000 rpm 20 分間遠沈してその上清を
使用した。成績は生のまま $10 \%$ の濃度で用いた場合明

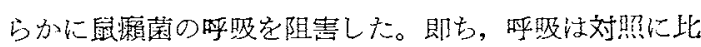
ベて 2 時間以内に $73 \%$ 以下となつた。が，非㗢化せる 場合は $20 \%$ 濃度に用いても無影響であつた。こ秃は あとで还べるように溶血した直液成分が阻害的に作用す るものと思礼る。

健康肝ミトコンドリア：Hogeboom のミトコンドリア 分離法(5)を心用してラット肝安処理し，ミトコンドリオ 浮游液を作或した。これを15\%の基質として用いたが 呼吸には無影響であつた。

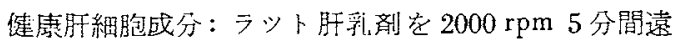
沈して粗大組織索除去し，上清老更に $10.000 \mathrm{rpm} 20$ 分

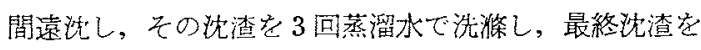
蒸溜水浮游液とした。こ机を $15 \%$ の基質として用いた が無影響かさしろゃや阻害的であつた。

肝鼠瀨腫抽出液：鼠瀨菌熊本珠を接種後約 8 万月劣経

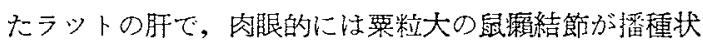
に撒布し肝の大部分は瀬腫で占放られてたものである。 敢てこの鼠瀨肝を用いた理由は, 健度肝組織に比べてこ のものは既に鼠舅菌発育の場として好適な細胞或はとの 成分がより多く造成されているのではないかと想像した からである。抽出液作成法は健康肝抽瑚液の場合と同様 にし，これを $20 \%$ 基質として用いたが，喛吸は 1 時間 以内に，生の肝鼠濑腫抽出液では $15 \%, 60^{\circ} \mathrm{C} 30$ 分非動

第 4 表 ラット血清及び臟器抽出淮の呼吸に及ぼす影響

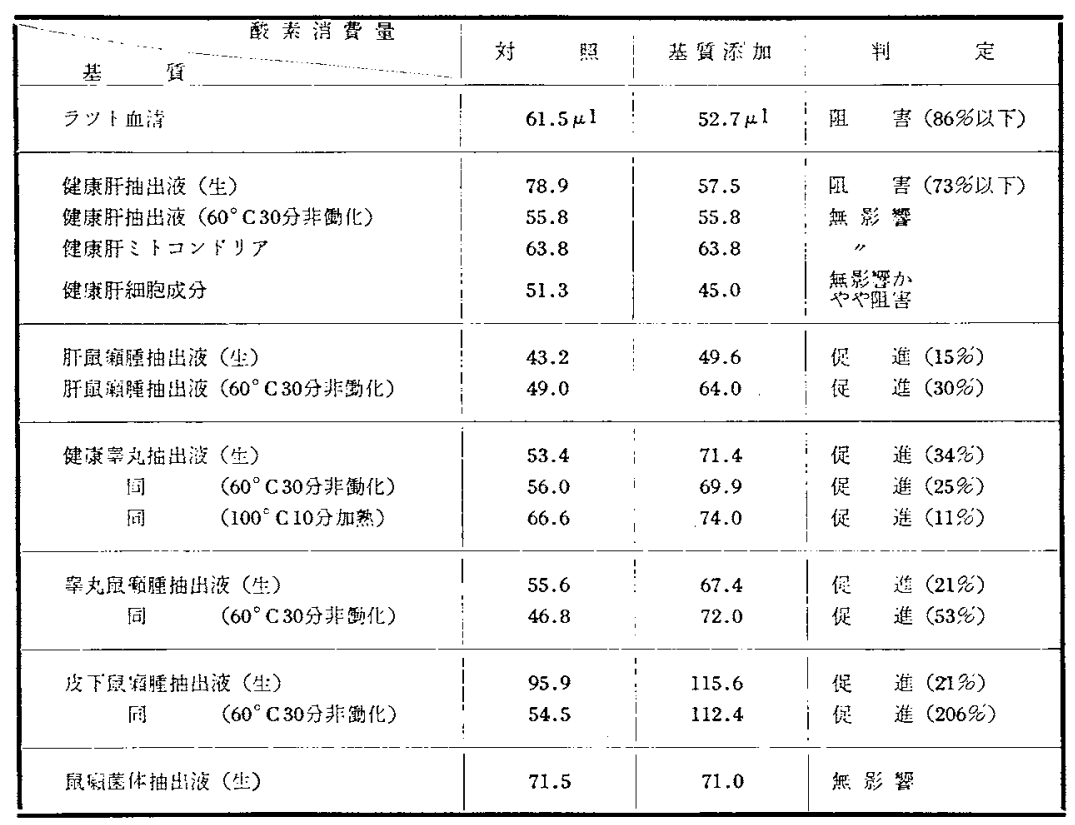


化子るものでは $30 \%$ と共に促進した。

健虚睪丸抽出液：ラット啐丸を上述と同様の方法で処 理した抽出液孛 $20 \%$ の基筫として用いたが，1時間以 内に生の抽出液では $34 \%, 60^{\circ} \mathrm{C} 30$ 分韭働化女るもので は $25 \% ， 100^{\circ} \mathrm{C} 10$ 分加熱せるものでも $11 \%$ 何れも呼 昅范促進した。

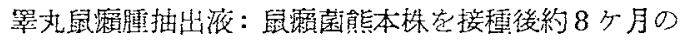

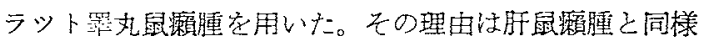
である。搔出法肝と同様にし，それ学 $20 \%$ 基質とし て用いたが，1時間以内に生の抽出液では $21 \% ， 60^{\circ} \mathrm{C}$ 30 分非㗢化せるものでは $53 \%$ と共に呼吸を促進した。

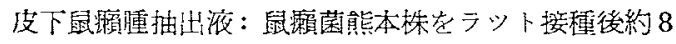
ケ月の皮下鼠瀨腫を上述の方法で好理し，その拉出液を $20 \% 0$ 基筫として用いたが，1時間以内に生の抽出液で は $21 \% ， 60^{\circ} \mathrm{C} 30$ 分韭㗢化せるものでは対照に化べて約 $200 \%$ 西昅促進が見られた。

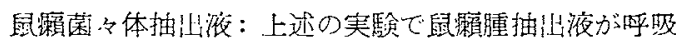
を促進したので，その促進物筫が鼠霓腫抽出液中に当然 含まれる菌体成分とどのような関係にあるかをみるため に，鼠整菌抽幽液を作つてその影響岂みた。菌体抽出液

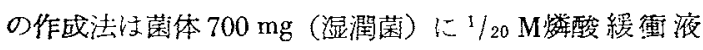

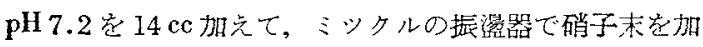
えて 1 時間期後， $10,000 \mathrm{rpm} 20$ 分間遠沈し，その上

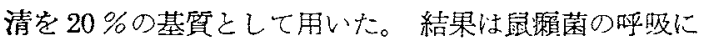
何らの影響を与えなかつた。

\section{総括及び考按}

トリプシン前処置集囷法によつて集的た鼠渍生菌が， 抗酸菌の栄荃素文は発育促進物資として既に知られた 10

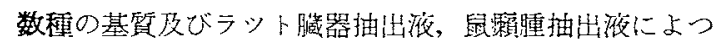
て，菌の脬吸面にどのような影響を受けるかるるるか К $1 / 5 \mathrm{M}$ 燐酸緩衝液 $\mathrm{pH} 7.2$ 在使用してワールブルグ検

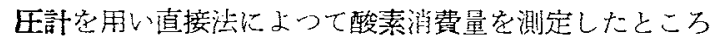
次の上うた成績妾得た。

1）基質它单独に用いた場合大部分のものは無影響であ つたが，ナスパラギンと酵母浮游液が呼吸を佂進し t。

2）基質䎞複合の形で用いた場合も大部分が無影響であ つた。殊にグリ七りンは学独で呼吸を促進した醉母孚 游液安添加しても影響を与えなかつた。しかしコハク 酸はラットの肝，翠丸抽出液及びモルモットの肝抽出 液学加えたことによつて著朋に㭔昨堂促進した。

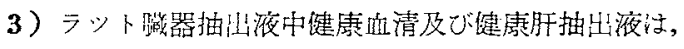
活性のままでは却つて乎吸を阻害した。しかし非働性
にすると無影響であつた。睪丸抽出液な活性のまま及 び $60^{\circ} \mathrm{C} 30$ 分， $100^{\circ} \mathrm{C} 10$ 分熱処理した場合，妈理によ つて\%は低下したがなすいずれもが乎吸学促淮した。

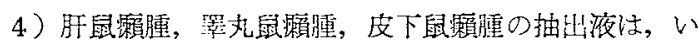

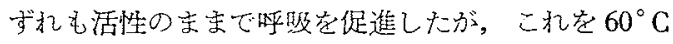

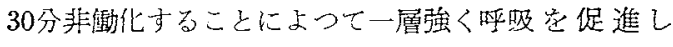
$t=0$

5）鼠癩菌体抽法液は舆影響であつた。

以上の成績を顧みるに，鼠製莉の呼吸が，一般抗酸菌 の物質代謝に宸素源としてよく利用されるダリセリンの

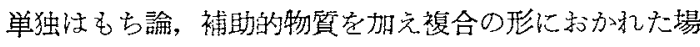
合にも無影響に終つていることは，站照に揭げた同一基 譬に対する山村(6)の鳥型結核囷における或績と比較して 鼠霜菌の外部基質の利用，即ら䤃素作用に子る外部代謝 の困難性を物語るすのとして生物学的にも兌だ重要な特

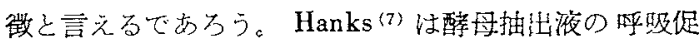
進它報じているが，我等の成績は無影響であつた。却つ て醉母浮游液の促進作用を認放た。しかしこの促進物筫 の本態はいまのところ全く不朋である。文7スパラギン

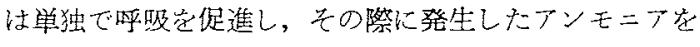
定量し得たが，これる今後更に十分なる研究を行いた $\checkmark$ 。

次に，TCA-cycleに觗与するコハク酸は単独基筫の 場合は乎吸定促進しないが，汗抽出液，罢丸拙出液を加 えて複合基質とした場合は明らかに呼吸安促進した。当

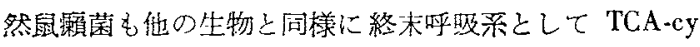

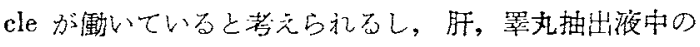

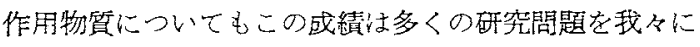
与えている。

ラットの值清及び蔵器抽纯液については可成り與味あ 万所見が得られた。即ら、活㻗清は乎吸を強く阻害し， 活肝抽汕液にもこの阻害作用を認めた。後者は抽出液の 作成操作において肝灌流を行わずそのまま用いたので立 液成分の我存せるためかと思われるが，又洗深肝細胞液 に和いても僅かに阻害がみられた点から考えて，生の体 液中では囷の生活が㧕医されるのであるうことは薿う余 地がない。既にHanks(8) も活南清にこの㭔吸阻富作用 のあることを啹じ，注意を照起している。而してこれら の阻青物算が $60^{\circ} \mathrm{C} 30$ 分加熟処理によつて除去されるこ とも亦與味あることである。肝のミトコンドリては無影

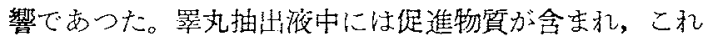
が $60^{\circ} \mathrm{C} 30$ 分, $100^{\circ} \mathrm{C} 10$ 分の熱观理によつて逐次\%は低

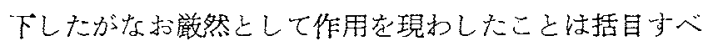
き所見である。Gray 㓐処理しだット睪丸抽法液は 
呼吸它促進しなかつたと報告しているが，恐らく熱好理 の万法の相異であるうと思われる。

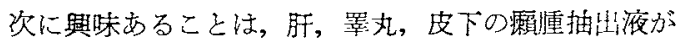
著しく㭔吸を促進し，これを不活化した場合一畠影著で あつたことである。この場合鼠演腫抽治液中に $10,000 \mathrm{r}$

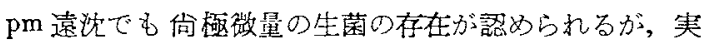
験対照の側窒にも闰一条件の抽出液を入れてあるので， この生菌による影響は無視しても良い。及破壊された菌 体成分による影響もさきに述べた菌体抽出液の実験成綪 からみて考慮の余地がないものと思われる。この鼠濑胜 抽出液はさきに酉村(9)等が同様のアイデフを以て鼠瀨菌 の管内培地に用いたが遂に好ましい結果文得るに至らな かつたものである。今四の成續は明らが鼠制菌堌殖組

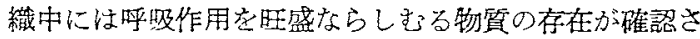
れたわけで, 今後, 前記の睪好拙出液と共にその成分の 息反に期待がかけられる。

\section{結論}

鼠灀菌の呼吸代謝に閣する実験成績を報告した。臼瀨 菌にダリセリン，コハク酸，V B 12 など 17 種の基質を

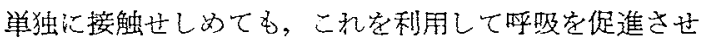
ることは出来なからたここのうちコハク酸は不活化訮抽 出液，睪丸抽出液の添加によつて呼吸を促進した。活血 清注却つて乎吸を阻害した。肝抽出液は活性では阻害し たが，不活化したものでは無影響であつた。睪丸抽出液 は単独でよく促進したが活性では強く，不活性では鼠か

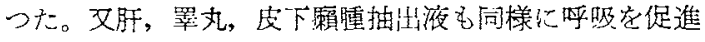
したが，こ秋は不活化において強かつた。

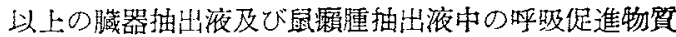
の追究は今後の課題として期待される。

終りに御指導御校閲定賜つた藤浪教授，西杜助教授に 深謝の意を表します。

\section{文献}

1) Clarke T. Gray: The Respiratory Metabolism of Murine Leprosy Bacilli. J. of Bact. 64305 (1952)

2) 中村 (昌)：白鼠に於ける鼠癩菌の増列態度（その 3）臼㵑菌の生体内 Slide culture 法の試多.レプ ラ 21，234（昭和 27)

3）占部，松尾，平本，牛尾：鳥瀨菌の生体内培養に関 する研究、レプラ 2515 (昭和 31 )

4) 伊藤, 園田: 籍菌の培養に関する研究.レプラ 26 No. 4 学会抄録 (昭和 32 )

5) Hogeboom, G. H., Schneider, W. C., and Palade, G. E.: Cytochemical studies of mammalian tissues. J. Biol. Cheul., 172 619-635., (1948)

6) 山村: 結核菌の生化学 95 (1955)

7) Hanks, J. H.: The biological significance of the hydrogen transfer capacity of murine leprosy bacilli. J. Bact. 62 529-537., (1951)

8) Hanks and Gray: The application of metabolic studies to leprosy research. Int. J. ofleprosy, 22 147 (1954)

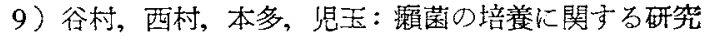
(第 3 報) レプシ 23319 (昭和 29) 